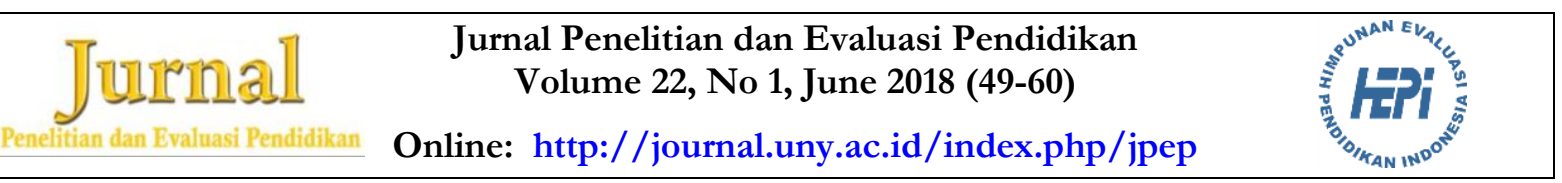

\title{
KEEFEKTIFAN PERANGKAT PEMBELAJARAN BERBASIS INQUIRY LESSON UNTUK MENINGKATKAN KETERAMPILAN BERPIKIR KRITIS SISWA
}

\author{
Susilowati ${ }^{1}$, Sajidan ${ }^{1}$, Murni Ramli ${ }^{1}$ \\ ${ }^{1}$ Universitas Sebelas Maret \\ ${ }^{1} J$ ln. Ir. Sutami No.36A, Jebres, Kota Surakarta, Jawa Tengah 57126, Indonesia \\ * Corresponding Author. Email: susilotwin@yahoo.co.id
}

\begin{abstract}
Abstrak
Penelitian ini bertujuan untuk mengetahui efektivitas Perangkat Pembelajaran Biologi untuk meningkatkan keterampilan berpikir kritis siswa. Tempat dan sampel penelitian dipilih secara purposive random sampling. Perangkat pembelajaran yang dikembangkan dan diteliti meliputi Rencana Pelaksanaan Pembelajaran (RPP), modul dan instrumen penilaian. Perangkat Pembelajaran tersebut dikembangkan berdasarkan indikator berpikir kritis menurut Facione yang terdiri dari enam aspek, yaitu: interpretasi, analisis, evaluasi, kesimpulan, penjelasan dan pengaturan diri. Instrumen yang dikembangkan, yaitu RPP, modul dan instrumen penilaian berupa tes telah diuji validitasnya dengan menggunakan formula Aiken $\mathrm{V}$ dengan indeks validitas secara berturut-turut sebesar 0,93, 0,92, dan 0,90. Adapun estimasi reliabilitas instrumen tersebut adalah 0,66, 0,69 dan 0,74. Hasil Uji efektivitas perangkat pembelajaran menggunakan $T$-test dan diperoleh p-value $0,00(\mathrm{p}<0,05)$ dengan score gap antara pre test dan post test sebesar 31,93\%, sehingga dapat disimpulkan bahwa perangkat pembelajaran guru kelas XI pada materi sistem ekskresi manusia efektif untuk meningkatkan keterampilan berpikir kritis siswa.
\end{abstract}

Kata kunci: efektivitas, perangkat pembelajaran, kemampuan berpikir kritis

\section{THE EFFECTIVENESS OF INQUIRY BASED LEARNING TOOLS FOR IMPROVING STUDENTS CRITICAL THINKING SKILLS}

\begin{abstract}
The research aims to determine the effectiveness of Biology learning device to improve students' critical thinking skills. The research sites and samples were chosen by purposive random sampling. The learning device developed and researched included the lesson plan (RPP), module and assessment instrument. The learning device was developed based on Facione's critical thinking indicator consisting of six aspects, including: interpretation, analysis, evaluation, conclusion, explanation, and self-regulation. The developed instruments, namely the lesson plan, module, and assessment instrument in the form of test had been tested for validity by using Aiken $\mathrm{V}$ formula with the validity index of $0.93,0.92$, and 0.90 respectively. The instrument reliability estimation is $0.66,0.69$. and 0.74 . The effectiveness of the learning device was tested using T-test andit obtains the $\mathrm{p}$-value of $0.00(\mathrm{p}<0.05)$ with score gap between pre test and post test at $31.93 \%$, so it can be concluded that the class XI teacher's learning tools on human excretion system material is effective to improve the students' critical thinking skill.
\end{abstract}

Keywords: effectiveness, lesson plan, critical thinking skills

Permalink/DOI: http:// dx.doi.org/10.21831/pep.v22i1.17836

Jurnal Penelitian dan Evaluasi Pendidikan

ISSN 1410-4725 (print) ISSN 2338-6061 (online) 


\section{Pendahuluan}

Keterampilan berpikir kritis merupakan salah satu kecakapan berpikir abad 21 yang perlu ditekankan pada bidang pendidikan (The Partnership for 21st Century Skills, 2015, p. 3). Keterampilan berpikir kritis dianggap sebagai pondasi keterampilan lain yang dibutuhkan diantaranya keterampilan komunikasi, keterampilan berkolaborasi, kesadaran global (global awareness), keterampilan teknologi, kecakapan dalam hidup dan karir, serta kemampuan belajar serta inovasi. Kemampuan berpikir kritis berguna untuk menstimulasi kemampuan lainnya, seperti berpikir logis, kreatif, memecahkan masalah, berpikir kritis, penguasaan teknologi serta kemampuan beradaptasi terhadap berbagai perubahan dan perkembangan zaman. Huitt (Friedel, Irani, Rudd, Gallo, Eckhardt, \& Ricketts, 2008, p.2) menyatakan bahwa berpikir kritis merupakan alat yang penting untuk meraih keberhasilan di abad 21. Zikovic (2016, p. 102) juga menyatakan bahwa model berpikir kritis merupakan atribut penting untuk sukses di abad 21.

Sternberg (1986, p. 6) menyatakan berpikir kritis adalah suatu proses mental, strategi dan representasi yang dilakukan oleh seseorang dalam memecahkan, menyusun keputusan serta dalam mempelajari konsep baru. Norris \& Ennis (1986, p. xvii) mendefinisikan berpikir kritis meliputi cara berpikir yang masuk akal (reasonable) dan reflektif yang berpusat pada keputusan tentang apa yang selanjutnya dipercaya ataupun dilakukan. Keterampilan berpikir kritis dapat diberdayakan melalui berbagai bidang diantaranya adalah bidang pendidikan. Didalam kegiatan pembelajaran pengembangan berpikir kritis dapat dilatihkan untuk mengembangkan keterampilan berpikir sejak dini.

Pendidikan di Indonesia mengamanatkan bahwa kemampuan berpikir kritis hendaknya dilatihkan pada peserta didik sejak dini. Dalam Kurikulum 2013 menyebutkan bahwa berpikir kritis merupakan salah satu tujuan pendidikan dan menjadi tuntutan kompetensi masa depan yang harus dikembangkan pada peserta didik (Kementerian
Pendidikan dan Kebudayaan, 2016, p. 10). Meskipun keterampilan berpikir kritis merupakan salah satu keterampilan masa depan yang disarankan oleh pendidikan di Indonesia, namun faktanya keterampilan berpikir kritis siswa di Indonesia masih tergolong rendah.

Hasil survei The Trends in International Mathematics and Science Study (TIMSS) (National Center for Educations Statistics, 2015, p. 1), menunjukkan bahwa kemampuan skor rata-rata sains peserta didik Indonesia adalah 397. Hasil tersebut jauh dibawah ratarata internasional sebesar 500 dan menduduki peringkat 4 terbawah dari seluruh negara partisipan. Demikian juga hasil penelitian Programme for International Student Assesment (Balitbang, 2013) diperoleh fakta bahwa kemampuan rata-rata siswa Indonesia dalam bidang matematika dan sains berada pada peringkat 64 dari total 65 negara partisipan. Mendukung temuan di atas, hasil penelitian Suratno \& Kurniati (2017, p. 2) menunjukkan bahwa ketertarikan siswa dalam hal membuktikan suatu prinsip maupun konsep, melakukan penyelidikan dan penggeneralisasian masih kurang. Siswa juga kurang tertarik dalam menyelesaikan soal yang bersifat non rutin. Sedangkan hasil penelitian Prihatni, Kumaidi, \& Mundilarto, (2016, p. 121) memperoleh fakta bahwa siswa lebih menguasai soal yang berbentuk ingatan dan hafalan tanpa memahami konsepnya. Siswa cenderung hafal dengan rumus-rumus dan tahapan-tahapan penyelesaiannya tanpa memahami konsep dan prosedur yang benar. Fakta tersebut menunjukkan bahwa kemampuan peserta didik Indonesia berada pada low order thinking.

Rendahnya pencapaian keterampilan berpikir kritis siswa ini menunjukkan adanya kesenjangan harapan dunia pendidikan dengan fakta yang terjadi di lapangan. Rendahnya keterampilan berpikir kritis siswa disebabkan oleh beberapa faktor yang mempengaruhi proses pembelajaran, bisa dari faktor guru, siswa, maupun faktor pendukung pelaksanaan pembelajaran lainnya. Keterampilan berpikir guru berperan dalam mengembangkan keterampilan berpikir kri- 
tis siswa. Demirhan \& Koklukaya (2013, p. 1551) dalam penelitiannya memperoleh fakta bahwa pemikiran kritis guru sains tergolong dalam kategori sedang dan rendah

Salah satu faktor pendukung keberhasilan pembelajaran adalah bahan ajar. Bahan ajar didefinisikan sebagai segala bentuk bahan yang disusun secara sistematis untuk membantu guru/instruktur dalam melaksanakan kegiatan pembelajaran dan memungkinkan siswa untuk belajar (Kementerian Pendidikan dan Kebudayaan, 2010, p. 26). Bahan ajar dapat berupa bahan cetak, seperti hand out, buku, lembar kegiatan siswa (LKS), modul, brosur atau leaflet, wachart, foto/gambar, ataupun model/maket (Kementerian Pendidikan dan Kebudayaan, 2010, p. 27). Bahan ajar berfungsi sebagai pedoman bagi guru untuk mengarahkan aktivitas selama proses kegiatan belajar mengajar berlangsung. Buku pelajaran adalah salah satu sumber belajar yang memiliki peran cukup besar dalam proses belajar siswa. Sitepu (2005, p. 116) menyatakan bahwa buku teks pelajaran juga memiliki kemampuan sebagai pendorong peningkatan mutu proses maupun hasil pembelajaran. Berdasarkan hasil prasurvei diperoleh fakta bahwa di Madrasah Negeri Kabupaten Magetan belum menggunakan modul sebagai bahan ajar, padahal hasil wawancara dengan siswa, diperoleh fakta bahwa mereka senang dan merasa termotivasi ketika dalam kegiatan belajar mengajar menggunakan modul.

Seorang guru dituntut untuk merencanakan apa yang akan dilakukan dalam mengelola kegiatan pembelajaran. Penyusunan Rencana Pelaksanaan Pembelajaran (RPP) sangatlah penting karena RPP mencakup desain pembelajaran yang dibuat dan dirancang, untuk selanjutnya dilaksanakan dalam kegiatan belajar mengajar untuk mencapai tujuan yang diinginkan. Keberadaan RPP diharapkan akan memperlancar, mengefektifkan, dan mengoptimalkan mutu proses pembelajaran. Rancangan, perencanaan pembelajaran didesain dalam bentuk Silabus. Perencanaan pembelajaran setidaknya meliputi penyusunan rencana pelaksanaan pembelajaran, penyiapan media dan sumber belajar, perangkat penilaian pembelajaran, dan skenario pembelajaran. (Kementerian Pendidikan dan Kebudayaan, 2016, p. 5). RPP dikembangkan dari silabus untuk mengarahkan kegiatan pembelajaran peserta didik dalam upaya mencapai Kompetensi Dasar (KD). Setiap pendidik diharapkan mampu menyusun RPP secara lengkap dan sistematis agar terlaksana pembelajaran yang interaktif, inspiratif, menantang, menyenangkan, efisien dan memotivasi siswa berpartisipasi aktif, dan memberikan ruang yang cukup bagi prakarsa, kreativitas dan kemandirian sesuai bakat, minat, perkembangan fisik dan psikologis peserta didik (Kementerian Pendidikan dan Kebuda-yaan, 2016, p. 6).

Keterampilan berpikir kritis peserta didik dapat dikembangkan melalui model pembelajaran yang tepat. Di antara berbagai macam model pembelajaran yang dipercaya dapat melatihkan keterampilan berpikir kritis untuk siswa, adalah pembelajaran berbasis konstruktivistik (Thompson, 2011, p. 2). Vygotsky (Vijayaratnam 2009, p. 56) menyatakan dalam pembelajaran konstruktivistik siswa diberikan kesempatan untuk bereksperimen atau berinkuiri dan berinteraksi dengan teman sejawatnya untuk meningkatkan perkembangannya. Keterampilan berpikir kritis dapat dilatihkan melalui model pembelajaran berbasis inkuiri sesuai tuntutan Kurikulum 2013 melalui pendekatan ilmiah. Lawson (1995, p. 200) menyatakan bahwa pembelajaran biologi di sekolah menengah dalam kurikulum yang berbasis inkuiri mampu memberdayakan keterampilan berpikir kritis dan penguasaan konsep siswa.

Karakteristik RPP, modul dan instrumen berbasis inquiry lesson adalah memuat sintaks pembelajaran inquiry lesson dan diintegrasikan dengan aspek berpikir kritis. Perangkat pembelajaran inquiry lesson yang dikembangkan oleh peneliti mengacu pada Facione (2015, p. 8) yang meliputi enam tahap yaitu; interpretasi, analisis, inferensi, evaluasi, penjelasan serta pengaturan diri yang didesain untuk memotivasi siswa belajar secara mandiri dalam menemukan prinsip, dan konsep materi pembelajaran. Sintaks inquiry lesson yang dimuat menurut 
Wenning (2011, p. 10) yaitu; observasi (observation) diintegrasikan dengan aspek interpretasi, manipulasi (manipulation) diintegrasikan dengan aspek analisis, generalisasi (generalization) diintegrasikan dengan aspek inferensi, verifikasi (verification) diintegrasikan dengan aspek evaluasi, dan aplikasi (aplication) diintegrasikan dengan aspek penjelasan dan pengaturan diri. Berdasarkan apa yang telah diuraikan, maka dirasa perlu dilakukan pengembangan perangkat pembelajaran yang dapat membantu guru dan siswa dalam melaksanakan pembelajaran berbasis inkuiri untuk meningkatkan keterampilan berpikir kritis siswa.

Berdasarkan uraian yang telah dipaparkan tersebut, penelitian ini bertujuan untuk mengetahui efektivitas perangkat pembelajaran Biologi untuk meningkatkan keterampilan berpikir kritis siswa.

\section{Metode Penelitian}

Penelitian ini merupakan penelitian deskriptif kualitatif dan kuantitaif yang dilakukan untuk mengetahui efektivitas perangkat pembelajaran pada materi sistem ekskresi manusia berbasis inquiry lesson dalam meningkatkan keterampilan berpikir kritis siswa. Tempat penelitian dipilih dengan purposive sampling dengan kriteria: (a) telah terakreditasi A menurut Badan Standar Nasional Pendidikan di Indonesia; (b) madrasah negeri yang memiliki jumlah siswa terbanyak pada Tahun Pelajaran 2016/2017; (c) guru telah memiliki pengetahuan dan melaksanakan pembelajaran berbasis inkuiri. Berdasarkan kriteria tersebut, penelitian ini dilaksanakan pada Madrasah Aliyah Negeri di Kabupaten Magetan.

Selanjutnya dipilih dua kelas secara random sampling, satu kelas ditetapkan sebagai existing class dan satu kelas sebagai experiment class. Hasilnya diperoleh subjek dalam penelitian adalah 22 siswa pada kelas MIA 2 sebagai kelas eksperimen dan 22 siswa kelas MIA 1 sebagai existing class. Kelas eksperimen diberikan pembelajaran menggunakan RPP, modul dan instrumen penilaian berdasarkan indikator berpikir kritis sedangkan pada kelas kontrol kegiatan belajar mengajar berlangsung seperti biasanya tanpa RPP, modul dan instrumen yang dikembangkan berdasarkan indikator berpikir kritis.

Data penelitian diperoleh melalui observasi, wawancara, angket, telaah dan tes. Observasi dilakukan untuk mencermati keterlaksanaan pembelajaran berbasis inkuiri pada proses belajar mengajar oleh guru di dalam kelas. Wawancara kepada guru dilakukan untuk mengetahui pengetahuan dan pemahaman guru terhadap pembelajaran inkuiri dan kebutuhan bahan ajar. Selain itu, Wawancara juga dilakukan untuk memperoleh informasi tentang kebutuhan bahan ajar siswa dan kesiapan siswa terhadap pembelajaran inkuiri. Kuisioner diberikan kepada siswa untuk mengetahui level inkuiri siswa. Tes kepada siswa dilakukan untuk mengetahui profil awal keterampilan berpikir kritis siswa, dan hasil keterampilan berpikir kritis siswa setelah menggunakan perangkat pembelajaran berbasis inquiry lesson, sedangkan tes kepada guru dilakukan untuk kemampuan guru dalam mengurutkan sintaks inquiry lesson.

Teknik analisis data yang digunakan dalam penelitian ini adalah teknik analisis deskriptif kualitatif dan kuantitatif. Teknik analisis kuantitatif digunakan untuk menghitung efektivitas perangkat pembelajaran, sedangkan analisis deskriptif kualitatif digunakan untuk menganalisis data tentang pengetahuan dan pemahaman guru terhadap pembelajaran inkuiri. Sebelum diterapkan di lapangan, perangkat pembelajaran telah melalui proses validasi yang dilakukan menggunakan formula Aiken's (Experts Judgement) dan diestimasi reliabilitasnya dengan koefisien Kappa. Selanjutnya, untuk mengetahui efektivitas perangkat pembelajaran dilakukan teknik analisis quasi experimental group berupa existing class dan experiment class yang dikembangkan dengan menggunakan desain Pre-test-post-test Control Group Design sebagaimana disajikan pada Tabel 1.

Tabel 1. Desain Penelitian

\begin{tabular}{cccc}
\hline Eksperiment Class & $\mathrm{O}$ & $\mathrm{X}_{1}$ & $\mathrm{O}_{1}$ \\
\hline Existing Class & $\mathrm{O}$ & $\mathrm{X}_{2}$ & $\mathrm{O}_{1}$ \\
\hline
\end{tabular}


$\mathrm{X} 1$ = Perlakuan, berupa pembelajaran menggunakan RPP, modul dan instrumen berbasis inquiry lesson

$\mathrm{X} 2$ = Pembelajaran seperti biasa yang dilakukan tanpa menggunakan RPP, modul dan instumen berbasis inquiry lesson

$\mathrm{O}=$ Pre-test (tes awal)

$\mathrm{O}_{1}=$ Post-test (tes akhir)

Uji efektivitas tersebut dilakukan dengan menggunakan uji beda Independent $T$ Test terhadap hasil pretes dan postes siswa untuk mengetahui perbedaan hasil pretes dan postes siswa. Tingkat efektivitas perangkat pembelajaran diuji dengan membandingkan gain score ternormalisasi $(<\mathrm{g}>)$ pada hasil pretest dan posttest baik pada existing class maupun experiment class. Hasil perhitungan gain score disajikan dalam Tabel 2.

Tabel 2. Kriteria Indeks N-gain dan Interpretasinya

\begin{tabular}{cc}
\hline$N$-Gain & Interpretasi \\
\hline $0,7<\mathrm{g}<1$ & Tinggi \\
$0,3 \leq \mathrm{g} \leq 0,7$ & Sedang \\
$0<\mathrm{g}<0,3$ & Rendah \\
\hline
\end{tabular}

(Sumber: Hake, 1998, p. 65).

\section{Hasil Penelitian}

Pengembangan Perangkat Pembelajaran

Perangkat pembelajaran berbasis inquiry lesson dikembangkan berdasarkan sintaks inquiry lesson yang terdiri dari (1) observation; pada tahap ini siswa diajak untuk mengamati fenomena yang disajikan, melibatkan siswa untuk memunculkan respon identifikasi permasalahan yang terdapat dalam fenomena tersaji; (2) manipulation; pada tahap ini siswa mengidentifikasi faktor-faktor yang mempengaruhi fenomena dan mengusulkan ide-ide yang memungkinkan untuk dilakukan penyelidikan; (3) generalization; pada tahap ini, siswa menggeneralisasi atau membuat kesimpulan atas dasar hasil temuannya; (4) verification; pada tahap ini siswa membuat prediksi dilanjutkan melakukan pengujian pada permasalahan lain yang serupa berda- sarkan konsep yang dioeroleh dari tahap sebelumnya selanjutnya mendiskusikannya kembali; (5) dan application; pada tahap ini guru memberi penguatan dan motivasi kepada siswa agar mampu menghasilkan penelitian kualitatif lainnya menggunakan media yang berbeda (Wenning, 2010, p. 9).

Karakteristik perangkat pembelajaran berbasis inquiry lesson dibandingkan perangkat lain adalah perangkat pembelajaran ini mengintegrasikan sintaks inquiry lesson dengan aspek berpikir kritis sehingga dharapkan siswa lebih terlibat aktif dalam menemukan konsep secara mandiri. Dalam model pembelajaran inquiry siswa didorong belajar tentang materi sains dan lebih memahami sifat-sifat sains (Zion, 2007, p. 424). Hal ini relevan dengan hakekat teori konstruktivisme, yang mensyaratkan siswa secara aktif terlibat untuk memperoleh pengertian yang ingin diketahuinya (Suparno, 1997, p. 49).

Uji validitas kelayakan perangkat pembelajaran berbasis inquiry lesson dilakukan melalui (1) uji coba lapangan awal yang melibatkan validator ahli materi, ahli pengembangan modul, ahli perangkat pembelajaran, praktisi (guru), dan 12 siswa (2) uji coba lapangan utama; dan (3) uji coba lapangan operasional.

Validasi telaah RPP, modul dan instrumen penilaian Hasil perhitungan formula Aiken's menunjukkan bahwa lembar telaah RPP memiliki koeffisien Aiken's V sebesar 0,93, modul sebesar 0,92 dan butir instrumen penilaian sebesar 0,90 . Hal ini berarti bahwa RPP, modul, dan butir instrumen penilaian memiliki validitas isi yang baik. (Aiken, 1985, p. 133).

Uji reliabilitas perangkat RPP menggunakan koefisien Kappa diperoleh hasil sebesar 0,659. Uji reliabilitas interrater pada modul diperoleh koefisien Kappa sebesar 0,686. Adapun Hasil analisis reliabilitas butir soal diperoleh Cronbach's alpha sebesar $0,757>0,423$ yang berarti semua butir soal reliabel.

Berdasarkan hasil observasi proses pembelajaran di kelas pada Madrasah tempat penelitian diperoleh fakta bahwa guru sudah melaksanakan pembelajaran berbasis 
inkuiri, namun dalam pelaksanaan, sintaks yang diterapkan belum lengkap dan masih didominasi discovery learning. Hal ini diperkuat dengan hasil angket level inkuiri siswa yang memperoleh data bahwa rata-rata keterampilan Discovery Learning sebesar 65,46\%, Interactive Demonsration sebesar 62,35\%, Inquiry lesson sebesar 51,82\%, Guided Inquiry Laboratory sebesar 42,50\% dan Bounded Inquiry Laboratory sebesar 30,42\%.

Berdasarkan hasil wawancara dan angket diketahui bahwa persepsi guru terhadap pembelajaran berbasis inkuiri dalam kategori cukup, dengan perolehan rata-rata $66,25 \%$. Sedangkan kemampuan rata-rata mengurutkan sintaks inkuiri menunjukkan hasil sebesar $50,35 \%$ dan dalam kategori kurang, dengan rincian sebagai berikut; persentase kemampuan mengurutkan sintaks pembelajaran inkuiri pada tahap pendahuluan sebesar $50,83 \%$ tergolong kategori kurang; tahap inti sebesar 68,80\% tergolong kategori cukup; dan pada tahap penutup sebesar 33,33\% dan tergolong kategori sangat kurang.

Hasil telaah bahan ajar berupa buku Biologi yang digunakan sebagai rujukan utama bagi guru dalam kegiatan pembelajaran terhadap pemberdayaan berpikir kritis diperoleh rata-rata sebesar 39,90\% dan tergolong dalam kategori kurang. Berdasarkan aspek kemampuan berpikir kritis siswa menunjukkan bahwa: (1) Aspek interpretasi rata-rata sebesar 47,60\%; (2) aspek analisis rata-rata sebesar $44,79 \%$; (3) aspek evaluasi rata-rata 33,89 ; 4) aspek kesimpulan diperoleh ratarata 40,82\%; (5) aspek penjelasan diperoleh rata-rata $45,44 \%$; (6) aspek pengaturan diri diperoleh rata-rata $26,90 \%$.

Setiap kegiatan dalam RPP, Modul dan instrumen penilaian berisi aktivitas terstruktur yang tersusun atas sintaks pembelajaran berbasis inquiry lesson yang diintegrasikan dengan aspek berpikir kritis. Tahap observasi diintegrasikan dengan aspek interpretasi, sedangkan tahap manipulasi diintegrasikan dengan aspek analisis. Selama ini guru belum pernah menyusun modul pembelajaran secara mandiri. Bahan ajar yang digunakan bersumber dari penerbit. Bahkan bahan ajar terbitan beberapa tahun lalu yang berbasis KTSP pun masih digunakan dengan alasan materi yang disajikan masih relevan dengan Kurikulum 2013.

Hasil wawancara dengan siswa diketahui bahwa siswa merasa lebih bersemangat belajar menggunakan modul daripada LKS yang selama ini mereka gunakan. Hal ini dikarenakan modul memiliki gambar yang lebih jelas dan besar, serta warna yang lebih menarik. Tahapan dalam modul juga membuat siswa lebih mudah untuk memahami konsep materi yang sedang dipelajari.

Perangkat pembelajaran dikembangkan dengan menggunakan lima langkah sintaks pembelajaran Inquiry lesson yang diintegrasikan dengan enam aspek berpikir kritis. Materi sistem ekskresi manusia dibagi menjadi tiga kegiatan, yaitu sistem ekskresi pada ginjal, sistem ekskresi pada kulit dan sistem ekskresi pada hati dan paru-paru.

Tahap generalisasi diintegrasikan dengan aspek inferensi, tahap verifikasi diintegrasikan dengan aspek evaluasi dan tahap aplikasi diintegrasikan dengan aspek penjelasan dan pengaturan diri.

Tabel 3. Hasil Analisis Deskriptif Skor Pretest dan Posstest

\begin{tabular}{|c|c|c|c|c|c|c|}
\hline Jenis Tes & Kelas & $\sum$ & Mean & Std & Min & Maks \\
\hline \multirow[t]{2}{*}{ Pretes } & existing & 22 & 46,6 & 6,97 & 32,5 & 67,50 \\
\hline & Exsperiment & 22 & 48,2 & 6,34 & 42,5 & 67,50 \\
\hline Rata-Rata & & & 47,5 & 6,65 & 32,5 & 67,50 \\
\hline \multirow[t]{2}{*}{ Postes } & existing & 22 & 60,0 & 5,61 & 32,8 & 77,50 \\
\hline & Exsperiment & 22 & 80,1 & 6,38 & 60,0 & 90,00 \\
\hline Rata-Rata & & & 70,1 & 5,99 & 46,4 & 83,75 \\
\hline
\end{tabular}

Tabel 3 menunjukkan hasil analisis deskripsi kemampuan berpikir kritis siswa sebelum diberikan perlakuan dan setelah dilakukan perlakuan pada existing class (pembelajaran biasa) dan experiment class (menggunakan perangkat pembelajaran berbasis inquiry lesson). Rata-rata skor pre test kelas kontrol adalah sebesar 46,6; dengan standar deviasi 6,97 ; skor minimum 32,5 ; dan maksimum 67,5. Rata-rata skor pada pretest kelas eksperimen sebesar 48,2; dengan standar deviasi 6,34 ; skor minimum 42.5 dan maksimum 67,50. Rata-rata post test kelas kontrol 
adalah sebesar 60,07 ; dengan standar deviasi 5.61; skor minimum 32,78 dan skor maksimum 77,50. Rata-rata postest kelas eksperimen adalah sebesar 80,12; dengan standar deviasi sebesar 6,38; skor minimum 60,09 dan skor maksimum 90,00.

\section{Efektivitas Perangkat Pembelajaran}

Untuk mengetahui keefektifan perangkat pembelajaran berbasis inquiry lesson dilakukan independent t test. Hasil uji independent $t$ test menunjukkan indeks korelasi sebesar 0,475 > 0,05 dan sig 2-tailed 0,00 sebagaimana disajikan dalam Tabel 4.

Tabel 4. Analisis T-test pada Kelas Eksperimen (MIA 2)

\begin{tabular}{cccc}
\hline Uji & Hasil & Keputusan & Kesimpulan \\
\hline T test & $\begin{array}{c}\text { Sig 2-tailed } \\
=000\end{array}$ & $\begin{array}{c}\text { Sig 2 tailed }< \\
0.05 \text {, sehingga }\end{array}$ & Terdapat \\
& & perbedaan \\
& & Ho ditolak & antara hasil \\
& & & pretes dan \\
& & & postes \\
\hline
\end{tabular}

Dalam rangka mengetahui perbedaan hasil pretest dan posttest pada kelas kontrol dan kelas eksperimen dilakukan penghitungan $N$-gain skor pada pretest dan posttest sebagaimana Gambar 1.

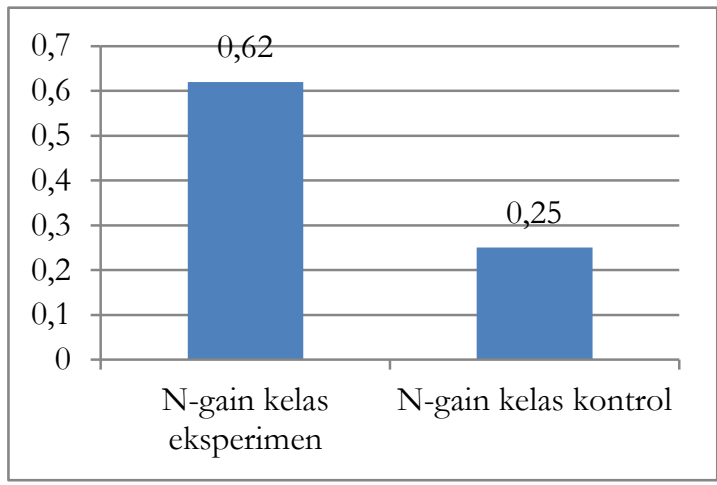

Gambar 1. Histogram N-gain Kelas Eksperimen dan Existing Class

Dari Gambar 1 diketahui bahwa Ngain hasil pretes dan postes pada kelas eksperimen adalah sebesar 0,62 dalam kategori sedang, sedangkan $\mathrm{N}$-gain pada kelas kontrol antara hasil pretes dan postes diperoleh 0,25 dalam kategori rendah. Berdasarkan hal tersebut diketahui bahwa terdapat perbedaan keterampilan berpikir kritis siswa baik pada kelas kontrol maupun kelas eksperimen, namun perbedaan pada kelas kontrol lebih kecil dibandingkan dengan kelas eksperimen.

\section{Pembahasan}

Perangkat pembelajaran berbasis inquiry lesson merupakan perangkat yang terdiri dari Rencana Pelaksanaan Pembelajaran (RPP), Modul dan Instrumen penilaian yang didesain mengacu pada sintaks pembelajaran inquiry lesson dan diintegrasikan dengan aspek berpikir kritis pada materi sistem ekskresi manusia. Inquiry lesson merupakan salah satu tingkatan dari model pembelajaran level of inquiry, menurut Wenning (2010, p. 4) pembimbingan secara perlahan dilepaskan sehingga siswa dapat melakukan inquiry secara mandiri, namun guru tetap memberikan bimbingan dan mendukung dengan berbagai pertanyaan untuk membantu siswa melaksanakan proses penyelidikan.

Pada tahap observasi pelaksanaan pembelajaran menggunakan perangkat pembelajaran pada kelas eksperimen pada pertemuan ke-1 menunjukkan bahwa siswa sangat antusias dalam mengikuti pembelajaran, meskipun siswa belum memahami perbedaan membuat identifikasi masalah dan merumuskan masalah. Pada tahap guru belum maksimal dalam memberikan motivasi. Pada pertemuan ke-2 siswa telah lebih memahami perbedaan antara identifikasi masalah dan rumusan masalah dan guru lebih tepat dalam memberikan motivasi kepada siswa.

Efektivitas perangkat pembelajaran ditunjukkan dengan adanya peningkatan keterampilan berpikir kritis siswa setelah dianalisis berdasarkan score N-Gain. Berdasarkan Gambar 1 diketahui rata-rata $N$-gain keterampilan berpikir kritis siswa existing class sebesar 0,25 atau termasuk dalam kategori rendah. Pada experiment class diperoleh $N$-gain sebesar 0,62 atau termasuk dalam kategori sedang. Peningkatan $N$-gain yang signifikan pada kelas eksperimen tersebut merupakan akibat dari penggunaan perangkat pembelajaran berbasis inquiry lesson yang mampu melatih dan meningkatkan keteram- 
pilan berpikir kritis siswa. Dalam desain RPP, modul dan instrumen penilaian disajikan fenomena ataupun permasalahan nyata yang ada di lingkungan siswa sehingga membantu siswa dalam menemukan konsep pengetahuan melalui proses penemuan. Pencapaian persentase keterampilan berpikir kritis masing-masing aspek indikator pretest dan posttest disajikan dalam Gambar 2.

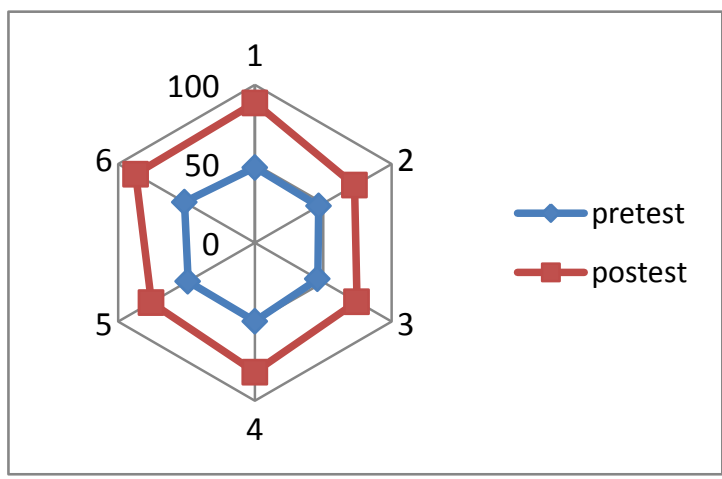

Gambar 2. Persentase Pencapaian Indikator Berpikir Kritis Siswa
1 : Interpretasi;
2 : Analisis;
3 : Inferensi;
4 : Evaluasi;
5 : Penjelasan;
6 : Pengaturan Diri

Hasil pretest rata-rata persentase keterampilan berpikir kritis siswa sebesar $52,28 \%$ tergolong kategori kurang. Persentase pada aspek interpretasi sebesar 48,80\% dalam kategori sangat kurang, aspek analisis sebesar 45,98\% dalam kategori sangat kurang, aspek evaluasi sebesar 53,39\% kategori sangat kurang, aspek kesimpulan sebesar $55,09 \%$ dalam kategori kurang; aspek penjelasan sebesar 46,48\% kategori sangat kurang, dan aspek pengetahuan diri sebesar 63,94\% kategori cukup. Sedangkan pada hasil postest diperoleh kenaikan rata-rata persentase $31,93 \%$ sehingga menjadi $80,12 \%$. Aspek interpretasi diperoleh rata-rata $88,67 \%$ kategori sangat baik, aspek analisis sebesar $72,92 \%$ kategori cukup, aspek inferensi sebesar 74,50\% kategori cukup, aspek evaluasi sebesar 81,83\% kategori baik, aspek penjelasan sebesar 75,75\% kategori cukup dan aspek pengaturan diri sebesar $87,08 \%$ tergolong kategori baik.

Hal ini relevan dengan yang dikemukakan dalam National Research Council
(1996, p. 13) yang menyatakan bahwa dalam proses pembelajaran guru sebagai bagian dari komunitas pembelajaran didalam kelas harus mampu menyusun perencanaan pembelajaran, membuat keputusan tentang apa yang akan dipelajari siswa, bagaimana cara mereka belajar, dan bagaimana sumberdaya dialokasikan secara berkelanjutan sehingga siswa fokus pada pembelajaran secara aktif bukan hanya sekedar hafalan, yang pada akhirnya terbangun basis pengetahuan dan pemahaman konsep. Dalam pembelajaran berbasis inkuiri siswa dilibatkan dalam penelitian, investigasi, mereka berinteraksi dengan guru dan teman sejawat. Siswa menerapkan pengetahuan mereka dan terlibat dalam pemecahan masalah, perencanaan, membuat keputusan, diskusi kelompok dan mereka mengalami penilaian yang konsisten dengan pendekatan aktif selama proses pembelajaran. Minner, Levy, \& Century (2010, p. 475) juga menyatakan pembelajaran inquiry dipercaya sebagai salah satu model konstruktivisme yang didalamnya membangun proses pengetahuan siswa melalui penyelidikan fenomena ilmiah. Dalam pendekatan inquiry lesson siswa dilibatkan secara kelompok maupun individu dalam kegiatan inkuiri. Hal ini diharapkan terjadinya kerja sama dan saling membantu antarsiswa dalam belajar. Josef, Trnova, \& Sibor (2012, p. 208) memperoleh fakta berdasarkan penelitiannya bahwa pembelajaran sains berbasis inquiry berhasil diterapkan sebagai salah satu metode pembelajaran karena mendorong motivasi siswa dalam belajar. Hal ini relevan dengan hasil pengamatan dan wawancara selama kegiatan belajar mengajar berlangsung, bahwa siswa lebih termotivasi dan lebih menyukai kegiatan belajar mengajar yang dalam prosesnya melibatkan siswa secara aktif baik dalam eksperimen, maupun observasi. Demikian juga menurut teori Vygotsky bahwa fungsi mental yang lebih tinggi pada umumnya muncul dalam percakapan dan kerja sama antar-individu sebelum fungsi mental yang lebih tinggi itu terserap kedalam individu tersebut (Trianto, 2010, p. 76).

White, et al. (2009, p. 30) mengemukakan bahwa keterampilan berpikir kritis 
siswa dapat ditingkatkan dengan mengimplementasikan pembelajaran yang berpusat pada siswa (student centered learning). Dalam kegiatan pembelajaran berbasis inquiry lesson siswa diarahkan untuk melakukan percobaan ilmiah dan bertindak layaknya seorang peneliti dalam setting penelitian formal. Siswa dalam hal ini harus dapat mendefinisikan sistem, menentukan variabel dependen dan independen yang melibatkan variabel kontrol dan manipulasi. Jadi proses pembelajaran lebih berpusat pada siswa, sedangkan guru bertindak sebagai fasilitator dan mediator (Wenning, 2011, p. 5). Siswa dituntut lebih aktif dalam menemukan konsep secara mandiri, sedangkan guru memberikan bimbingan, panduan dan membantu siswa untuk melakukan eksperimen, identifikasi, pengendalian variabel dan pendefinisian. Kasmurie, Abdul, \& Ahmad, (2010, p. 272) membuktikan bahwa pembelajaran inquiry mampu meningkatkan keterampilan berpikir kritis siswa, sehingga perlu ditekankan pada setiap sekolah sebagai salah satu alternatif metode pembelajaran disekolah. Hal ini selaras dengan hasil penelitian Purwanto (2013, p. 110) bahwa dengan model pembelajaran level of inquiry dapat melatihkan kemampuan berinkuiri siswa yang didalamnya sejalan dengan indikator keterampilan berpikir kritis siswa.

Pembelajaran berbasis inkuiri yang diintegrasikan dengan modul memberikan hasil yang signifikan dalam meningkatkan keterampilan berpikir kritis siswa. Kumari \& Kulshrestha (2013, p. 5) memperoleh hasil bahwa pembelajaran berbasis inquiry yang diintegrasikan dengan modul menjadikan pengalaman belajar siswa menjadi jauh lebih bermakna dan lebih terlibat aktif dalam kegiatan belajar mengajar. Perangkat pembelajaran berbasis inquiry lesson merupakan perangkat yang didesain dengan memuat permasalahan yang terjadi di lingkungan yang memerlukan pembuktian proses eksperimen melalui metodologi ilmiah yang menstimulasi siswa untuk menemukan konsep secara mandiri sehingga menghasilkan penemuan yang bermakna. Hal tersebut relevan dengan teori belajar Ausubel bahwa berusaha sendiri untuk mencari pemecahan masalah serta pengetahuan yang menyertainya sehingga menghasilkan pengetahuan yang benar-benar bermakna (Dahar, \& Wilis, 2011, p. 134). Selaras dengan pernyataan Buffington (2007, p. 22) bahwa keterampilan berpikir kritis siswa dapat berkembang apabila dalam kegiatan belajar mengajar secara periodik guru melibatkan keterampilan berpikir kritis dalam tahapannya. Hal senada diupayakan dalam perangkat pembelajaran berbasis inquiry lesson, dalam RPP, dan modul berisikan kegiatan pembelajaran secara periodik memuat keterampilan siswa untuk mengobservasi, menginterpretasi data, menganalisis, menjelaskan. L. M. Sartorelli dan R. Swartz (Hossoubah, 2007, pp. 96110) menyatakan bahwa ada beberapa cara dalam usaha peningkatan keterampilan berpikir kritis siswa diantaranya: (1) membaca secara kritis; (2) mengembangkan daya analisis pada suatu permasalahan melalui kegiatan diskusi untuk mengatasi permasalahan tersebut, mencari solusi terbaik dan mempertimbangkan dampak positif dan negatifnya; (3) mengembangkan kemampuan mengamati atau observasi, mengidentifikasi kelebihan dan kekurangannya, pro-kontra dari permasalahan tersebut; (4) meningkatkan rasa ingin tahu siswa, menggali kemampuan bertanya dan refleksi, mengajukan pertanyaan berkualitas yang tidak hanya membutuhkan jawaban benar dan salah saja. Dalam perangkat pembelajaran berbasis inquiry lesson secara berurutan disajikan fenomena untuk kegiatan observasi melatih keterampilan interpretasi siswa, tahap manipulasi untuk melatihkan analisis siswa, tahap generalisasi melatih keterampilan siswa dalam menyusun kesimpulan, tahap verifikasi melatihkan evaluasi siswa, dan tahap aplikasi untuk melatih keterampilan penjelasan dan pengaturan diri siswa sehingga pada ahkirnya keterampilan berpikir kritis siswa secara umum dapat meningkat.

\section{Simpulan}

Kesimpulan dari penelitian ini adalah perangkat pembelajaran berbasis inquiry lesson efektif dalam meningkatkan keteram- 
pilan berpikir kritis siswa pada materi sistem ekskresi manusia. Meskipun pada pertemuan pertama siswa merasa ada beberapa hambatan yang dialami, diantaranya siswa masih belum terbiasa dalam menyusun rumusan masalah dan hipotesis. Namun hal tersebut sudah berjalan baik pada pertemuan selanjutnya. Hasil uji statistik diperoleh perbedaan signifikan antara hasil pretest dengan hasil posttest pada kelas eksperimen dengan kategori sedang. Sedangkan pada existing class menunjukkan perbedaan hasil pretest dengan posttest yang lebih rendah dibandingkan dengan gap pada kelas eksperimen dengan kategori rendah.

Adapun saran bagi peneliti lanjut, hasil penelitian ini dapat digunakan sebagai dasar untuk melakukan penelitian terkait dengan proses berpikir kritis siswa khususnya siswa yang memiliki kesamaan kondisi dengan siswa di Madrasah tempat penelitian ini dilakukan. Selain itu, perlu dilakukan uji coba lebih lanjut untuk memperoleh data yang akurat tentang perkembangan berpikir kritis siswa dengan mengacu pada indikator berpikir kritis menurut ahli yang lain seperti Ennis, Paul dan lainnya dan dilaksanakan pada bidang pelajaran yang berbeda.

\section{DAFTAR PUSTAKA}

Aiken, L. R. (1985). Three coeffecients for analyzing the reability and validity of rating. Educational and Psychological Measurement, 45, 131-142.

Balitbang.(2013). Survey internasional PIS A (Programme for International Student Assessment student). Jakarta:

Kementerian Pendidikan dan Kebudayaan. Retrieved November 17, 2017 from http://litbang.kemdikbud.go.id/index. $\mathrm{php} /$ survey-internasional-pisa

Buffington, M. L. (2007) Contemporary approaches to critical thinking and the wold wide web. Art Education, 60(1), 18-23.

Dahar, D. \& Wilis, R. (2011). Teori-teori belajar dan pembelajaran. Jakarta:

\section{Erlangga.}

Demirhan, E., \& Koklukaya, A. N. (2013). The critical thinking dispositions of prospective science teachers. In $5 s t$ world Conference on Educational Sciences WCES 2013. Procedia Social and Behavioral Sciences, 116, 1551-1555.

Facione, P.A. (2015). Critical thinking : what it is and Why it Count. Retrieved

December 17, 2017 from http://www.insightassessment.com/c ontent/download/1176/7580/file/wh at/26why2010.pdf

Friedel, C., Irani, T., Rudd, R., Gallo, M., Eckhardt, E., \& Ricketts, J. (2008). Overtly teaching critical thinking and inquiry-based learning: A comparison of two undergraduate biotechnology classes. Journal of Agricultural Education, 49(1), 72-84. Retrieved from http://step.ufl.edu.resources/critical thinking/ctmanual.pdf

Hake, R. (1998). Interactive-engagement versus traditional methods: A sixthousand-student survey of mecanics test data for introductory physics courses. American Journal of Physics, 66(1), 64-74.

Hossoubah, Z. (2007). Developing creative and critical thinking skills (Terjemahan). Bandung: Yayasan Nuansa Cendekia.

Josef, T., Trnova, E., \& Sibor, J. (2012). Implementation of inquiry based science education in science teacher training. International Journal On New Trend In Education And Their Implication, 2, 199-20.

Kasmurie, A. K, Abdul, R. A., \& Ahmad, A. S. (2010). The effectiveness of inquiry teaching in enhancing students critical thinking. Procedia Social and Behavioral Sciences, 7(C), 264-27.

Kementerian Pendidikan dan Kebudayaan. (2010). Juknis pengembangan bahan ajar SMA. Jakarta: Kementerian Pendidikan dan Kebudayaan Republik Indonesia. 
Kumari, K., \& Kulshrestha, A. K. (2013). Impact of contstructivist inquiry-based learning approach on science achievement at grade VIII. International Journal of Aplied and Studies, 2, 1-5.

Lawson, A. E. (1995). Science teaching and the development of thinking. California: Wadsworth Publising Company.

Minner, D. D., Levy, A. J., \& Century, J. (2010). Inquiry-based science instruction-What is it and does it matter. results from a research synthesis Years 1984 to 2002. Journal of Research in Science Teaching, 47, 474-494.

National Center for Educations Statistics. (2015). Trends in international mathematics and science study (TIMMS): Science for grades 4 and 8: everages. Retrieved December 15, 2017, from https://nces.ed.gov/timss/,

National Research Council. (1996). National science education standards. Washington, D.C.: National Academies Press.

Norris, S. P., \& Ennis, R. H. (1989). Evaluating crivtical thinking. Critical Thinking Press \& Sotfware.

Kementerian Pendidikan dan Kebudayaan. (2016) Permendikbud Nomor 22 Tahun 2016 Tentang Standar Proses Pendidikan Dasar dan Menengah. (. Jakarta. Kemdikbud Republik Indonesia

Purwanto. (2013). Analisis kemampuan inkuiri dan hasil belajar siswa sekolah menengah pertama melalui model pembelajaran berbasis model hierarki of inquiry. In Prosiding Pertemuan Ilmiah XXVII HFI Jateng \& DIY, 107-110.

Sitepu, M. A. (2005). Memilih buku pelajaran. Jurnal Pendidikan Penabur, 4, 113-126.

Suparno, P. (1997). Filsafat konstruktivisme dalam pendidikan. Yogyakarta: Kanisius.

Sternberg, R. J. (1986). Critical thinking it's measurement, and improvement. Jurnal National Inst. Education, (ED), 1-37.

Suratno, S., \& Kurniati, D. (2017).
Implementasi model pembelajaran math-science berbasis performance assessment untuk meningkatkan kemampuan berpikir kritis siswa di daerah perkebunan kopi Jember. Jurnal Penelitian Dan Evaluasi Pendidikan, 21(1), 1-10. https://doi.org/10.21831/pep.v21i1.1 1799

The Trends In International Maths and Science Study. (2015). Wold Pupil Rankings In Science And Maths 2015. Retrieved December 5, 2017 from www.telegraph.co.uk,

The Partnership for 21st Century Skills (2015). A Framework for 21 st century learning. Retrieved October 1, 2017, from www.p21.org

Thompson, C. (2011). Crotical across the curriculum: procces over output. International Journal of Humanisties and Social Science, 1(9), 1-7.

Trianto. 2010. Mendesain model pembelajaran inovatif progresif: konsep, landasan, dan implementasinya pada kurikulum tingkat satuan pendidikan (KTSP). Jakarta: Kencana.

Vijayaratnam, P. (2012). Developing higher order thinking skills and team commitment via group problem solving: A bridge to the real world. Procedia Social and Behavioral Sciences 66, 53-63.

Wenning, C.J. (2010). Levels of inquiry: Using inquiry spectrum learning sequences to teach science. Journal of Physics Teacher Education Online, 5(4), 1119

Wenning, C. J. (2011). The levels of inquiry model of science teaching. Journal of Physics Teacher Education,6 (2), 9-16.

White, T. K., Whitaker, P., Gonya, T., Hein, R., Kroening, D., Lee, K., Lee, L., Lukowiak, A., \& Hayes, E. (2011). The use of interupted case studies to enhance critical thinking skills in Biology. Journal of MicroBiology and 
Biology Education, 10, 25-31.

Prihatni, Y., Kumaidi, K., \& Mundilarto, M. (2016). Pengembangan instrumen diagnostik kognitif pada mata pelajaran IPA di SMP. Jurnal Penelitian Dan Evaluasi Pendidikan, 20(1), 111-125. https://doi.org/10.21831/pep.v20i1.7 524

Zion. (2007).The Spectrum of dynamic inquiry teaching practices. Research Science Education, 37, 423-447.

Zikovic, Z.(2016). A model of critical thinking as an important attribute for success in the 21 st century. In International Conference on Teaching and Learning English as an Additional Language, GlobELT 2016. Procedia Social and Behavioral Science, 232 (pp. 102-108). 